\section{ISOLATION AND CHARACTERIZATION OF PLASMID DNAS IN ACTINOMYCETES}

\author{
Masanori OKanishi and TaICHI Manome \\ Department of Antibiotics, National Institute of \\ Health, Kamiosaki, Shinagawa-ku, Tokyo 141, \\ Japan \\ Hamao Umezawa \\ Institute of Microbial Chemistry, \\ Kamiosaki, Shinagawa-ku, Tokyo 141, Japan \\ (Received for publication September 29, 1979)
}

Plasmid involvement in the production of various antibiotics in streptomycetes has been suggested by "curing" experiments ${ }^{1 \sim 3)}$ and, in some cases, it has been proved by genetic analysis of recombinants or by infectious transfer. ${ }^{4 \sim 7)}$ A few papers have been published on the isolation of plasmid DNA from streptomycetes, and following supercoiled DNAs (as plasmids) have been reported in antibiotic-producing streptomycetes: $3.35 \mu \mathrm{m}$ DNA in aureothricin-producing Streptomyces kasugaensis M338 (At-536) ${ }^{8}$, 18-megadalton DNA in chloramphenicol-producing Streptomyces sp. 3022a, ${ }^{92}$ plasmids pSF1 and pSF2 in neomycin-producing Streptomyces fradiae ATCC $10745,{ }^{10)}$ a plasmid in oxytetracycline-producing Streptomyces rimosus, ${ }^{11)}$ and SCP2(pSH1) in Streptomyces coelicolor A3(2).,13) We have attempted to isolate supercoiled DNAs from 32 strains of 30 actinomycete species and to determine their molecular weights by application of electron microscopy and restriction endonuclease analysis.

Organisms were inoculated into a seed medium (GGCY) consisting of $10 \%$ glucose, $0.1 \%$ glycine, $0.4 \%$ Casamino acids(Difco), $0.05 \%$ yeast extract (Difco), $0.1 \% \mathrm{MgSO}_{4} \cdot 7 \mathrm{H}_{2} \mathrm{O}, 0.01 \% \mathrm{CaCl}_{2} \cdot 2 \mathrm{H}_{2} \mathrm{O}$, $0.4 \%$ trace element solution, ${ }^{14)} 0.2 \% \mathrm{KH}_{2} \mathrm{PO}_{4}$ and $0.8 \% \mathrm{Na}_{2} \mathrm{HPO}_{4} \cdot 12 \mathrm{H}_{2} \mathrm{O}$, and were incubated at $27^{\circ} \mathrm{C}$ for 3 days on a reciprocating shaker. The seed culture was inoculated into GGC medium $(100 \mathrm{ml})$ which contained no yeast extract but $0.4 \%$ glycerol instead of glucose in the GGCY' medium. 2'-Deoxyadenosine ( $0.02 \%)$ and $150 \mu \mathrm{Ci}$ of ${ }^{3} \mathrm{H}$-thymidine were added to the medium for labeling DNA. After incubation for 24 hours at $27^{\circ} \mathrm{C}$, the mycelia were harvested, suspended in $35 \mathrm{ml}$ of $0.1 \mathrm{~N} \mathrm{NH}_{4} \mathrm{OH}$ containing $10 \mathrm{~mm} 3 \mathrm{Na}$-EDTA and incubated at $37^{\circ} \mathrm{C}$ for 20 minutes. After centrifugation, the sedimented mycelia were suspended in $20 \mathrm{ml}$ of $2 \times$ TES (TES consists of $25 \mathrm{~mm}$ Tris, $25 \mathrm{~mm} 2 \mathrm{Na}$-EDTA and $25 \mathrm{~mm} \mathrm{NaCl}, \mathrm{pH}$ 7.4). One $\mathrm{ml}$ of lysozyme solution $(40 \mathrm{mg} / \mathrm{ml})$ was added, and the suspension was incubated at $37^{\circ} \mathrm{C}$ until the mycelia showed about $50 \%$ lysis. Three $\mathrm{ml}$ of $10 \%$ sodium dodecyl sulfate (SDS) was added, the suspention incubated at $37^{\circ} \mathrm{C}$ for 20 minutes, and centrifuged at $20,000 \times g$ for 30 minutes at $20^{\circ} \mathrm{C}$ to obtain a cleared lysate. To the cleared lysate, $5 \mathrm{M} \mathrm{NaCl}$ was added to a final concentration of $1.0 \mathrm{M}$. The mixture was kept in ice bath for at least 2.5 hours, and the precipitate was removed by centrifugation $(1,200 \times g, 15$ minutes, $0^{\circ} \mathrm{C}$ ). To the supernatant fluid, RNase was added at a concentration of $50 \mathrm{mcg} / \mathrm{ml}$ and the solution incubated at $37^{\circ} \mathrm{C}$ for 20 minutes. After that, Pronase E solution (incubated for 1 hour at $37^{\circ} \mathrm{C}$ in advance) was added at $100 \mathrm{mcg} / \mathrm{ml}$ followed by incubation at $37^{\circ} \mathrm{C}$ for 20 minutes. Polyethylene glycol $6000(40 \%)$ was added to a concentration of $10 \%$ and the solution kept in a refrigerator overnight to precipitate DNA. The precipitated DNA was collected by centrifugation at $1,200 \times g$ for 10 minutes, and the sedimented material was dissolved in $4.7 \mathrm{ml}$ of TES buffer with careful stirring. The solution was dialyzed against TES buffer for at least 3 hours. Exactly $4.70 \mathrm{ml}$ of the dialyzed solution was taken and $\mathrm{CsCl}(5.00 \mathrm{~g})$ was added. Insoluble materials were removed by low speed centrifugation and $0.5 \mathrm{ml}$ of ethidium bromide solution $(4.8 \mathrm{mg} / \mathrm{ml})$ was added and the solution mixed. After centrifugation at $100,000 \times g$ for 42 hours, radioactivities of gradient fractions were measured in the usual manner. The fractions containing supercoiled DNA as well as chromosomal DNA were dialyzed against DSB (10 mM Tris, $10 \mathrm{~mm}$ $\mathrm{NaCl}, 1 \mathrm{~mm}$ 2Na-EDTA, pH 7.6), and samples were analyzed by agarose gel electrophoresis to detect plasmid DNA. Supercoiled DNA in the residual sample was purified by neutral sucrose gradient centrifugation.

DNA samples for electron microscopy were prepared by the formamide technique, ${ }^{15)}$ and molecular weights of DNAs were calculated from contour lengths which were obtained by taking pBR 322 DNA as internal standard. Four restriction endonucleases (Eco RI, Sal I, Bam HI, and Hind III) were used to digest plasmid DNA, and the samples were subjected to agarose gel electrophoresis to investigate the cleavage number and 
molecular weight of fragments.

Mycelia of most streptomycetes in the stationary phase of growth were lyzed easily by lysozyme, after growth in a chemically defined medium containing glycine $(0.1 \%)$ and glycerol at concentrations less than $0.4 \%$. Some strains which were only poor lyzed became sensitive to lysozyme when the mycelia were incubated in $0.1 \mathrm{~N} \mathrm{NH}_{4} \mathrm{OH}$ at $37^{\circ} \mathrm{C}$ for 20 minutes before the lysozyme treatment.

From 32 antibiotic-producing strains, supercoiled DNAs were found in 7 strains as follows: Streptomyces ribosidificus KCC S-0923 (ribostamycin), Streptomyces niveus KCC S-0599 (novobiocin), S. kasugaensis MB 273 (kasugamycin and aureothricin), Streptomyces violaceus-ruber SANK 95570 (methylenomycins), S. fradiae KCC S-0579 (ATCC 10745, neomycin), Streptomyces omiyaensis NIHJ AT-95 (chloramphenicol) and Streptoverticillium mashuensis KCC S-0059 (streptomycin). A satellite peak of DNA in dye-bouyant density gradient centrifugation was detected in cases of $S$. ribosidificus, S. niveus, $S$. kasugaensis, $S$. omiyaensis and $S$. fradiae. Typical patterns are shown in Fig. 1 A together with those of neutral sucrose gradient centrifugation (Fig. $1 \mathrm{C}$ ). No satellite peak was observed in Stv. mashuensis and S. violaceus-ruber, but their supercoiled DNAs were found by agarose gel electrophoresis in the fractions near fraction number 12 (Fig. 1 B). Electron microscopic photographs are shown in Fig. 2. Characteristics of each plasmid DNA are summarized in Table 1 .

Two plasmids were observed in $S$. fradiae ATCC 10745 and their molecular weights were calculated to $62 \times 10^{6}$ and $43 \times 10^{6}$ daltons. These values are different from those (14.9 and 21.9 $\times 10^{6}$ daltons) reported by YAGISAWA et al. ${ }^{10)}$ $S$. violaceus-ruber examined in this experiment produced methylenomycin A as did S. coelicolor A3(2) ${ }^{16 \sim 18)}$. Both may belong to the same species, since their phenotypic feature are identical. Biosynthetic steps of methylenomycin A in $S$. coelicolor $\mathrm{A} 3(2)$ have been reported to be controlled by genes on plasmid SCP1, although this plasmid DNA has not yet been isolated. ${ }^{6)}$ In our S. violaceus-ruber, however, a $100 \times 10^{6}$ dalton plasmid (pSV1) was detected. It will be interesting to examine the relationship between pSV1 and methylenomycin A production.

Among 32 strains examined, it was found that only 7 strains had supercoiled DNA. Furthermore, supercoiled DNAs were not found in

Fig. 1. CsCl-ethidium bromide density gradient centrifugation of ${ }^{3} \mathrm{H}$-labeled DNA isolated from $S$. ribosidificus KCC S-0293 (A) and Stv. mashuensis KCC S-0059 (B).

Neutral sucrose gradient centrifugation of ${ }^{3} \mathrm{H}$-labeled DNA obtained from above density gradient centrifugation, S. ribosidificus (C) and Stv. mashuensis (D).
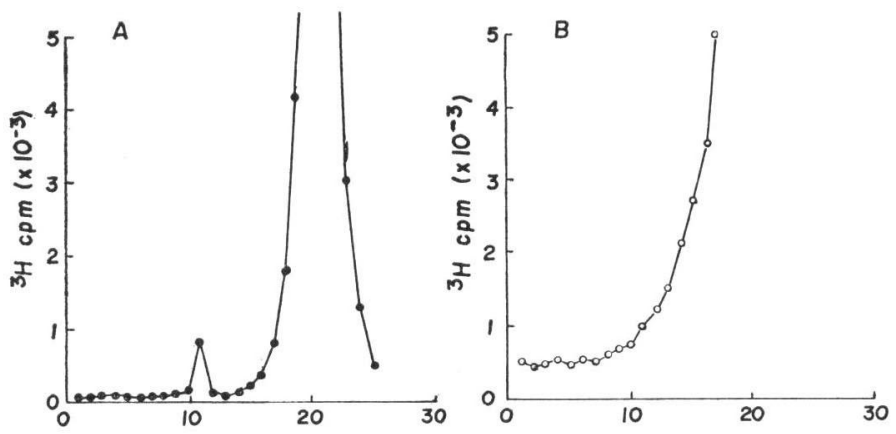

c

D

Fig. 2. Electron micrographs of plasmid DNAs.

(A) pSR1 DNA of $S$. ribosidificus KCC S-0923.

(B) pSM1 DNA of Stv. mashuensis KCC S-0059.

(C) pSO1 DNA of $S$. omiyaensis NIHJ AT-95.

(D) pSN1 DNA of $S$. niveus KCC S-0599.

The molecular weight of the plasmid was determined by use of the pBR322 as internal standard $(2.6 \times$ $10^{6}$ claltons). Bar corresponds to $1 \mu \mathrm{m}$.
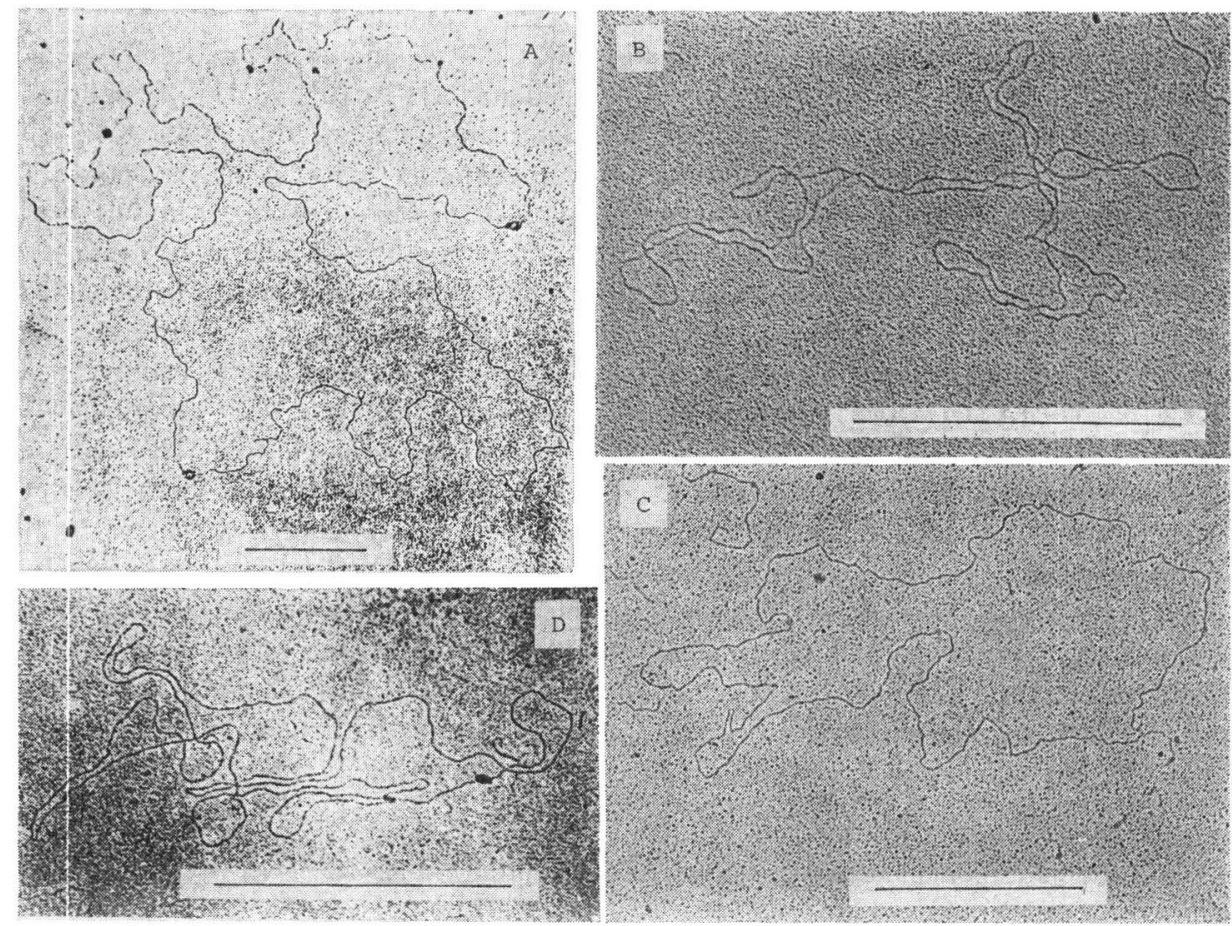

Table 1. Characterization of actiomycete plasmids.

\begin{tabular}{|c|c|c|c|c|c|c|c|}
\hline \multirow{2}{*}{ Plasmid } & \multirow{2}{*}{ Host } & \multicolumn{4}{|c|}{ Numbers of plasmid fragments } & \multicolumn{2}{|c|}{$\begin{array}{l}\text { Molecular weight } \\
\left(\times 10^{-6}\right)\end{array}$} \\
\hline & & Eco RI & Hind III & Bam HI & Sal I & $\mathrm{AGE}^{*}$ & $\mathrm{EM}^{* *}$ \\
\hline pSR1 & S. ribosidificus $\mathrm{KCC}$ S-0923 & 8 & 4 & 8 & +++ & 49 & 56 \\
\hline pSM1 & Stv. mashuensis KCC S-0059 & 0 & 0 & 2 & 8 & 16 & 17 \\
\hline pSN1 & S. niveus KCC S-0599 & 4 & 0 & 0 & $++t$ & 20 & 20 \\
\hline pSK1 & S. kasugaensis IMC MB273 & 1 & 0 & 2 & 1 & 6.7 & 6.7 \\
\hline pSO1 & S. omiyaensis NIHJ AT-95 & 2 & +++ & 2 & +++ & 18 & 19 \\
\hline pSV1 & $\begin{array}{l}\text { S. violaceus-ruber } \\
\text { SANK } 95570^{* * *}\end{array}$ & & & & & & 100 \\
\hline Large & S. fradiae ATCC 10745*** & & & & & & 62 \\
\hline Small & S. fradiae ATCC $10745^{* * *}$ & & & & & & 43 \\
\hline
\end{tabular}

* AGE: Agarose gel electrophoresis

** EM: Electron micrograph

*** These plasmid DNAs were not obtained enough amount to use for the restriction endonuclease experiments. 
strains of $S$. venezuelae and $S$. alboniger with which genetical studies suggested the possible plasmid involvement in antibiotic production. The reasons why supercoiled DNA was not detected in most strains tested may be as follows: (1) Our methods may have been still unsuitable to separate plasmid DNA from cell components or insufficient to inhibit the nuclease activity of the lyzed cells; (2) During the long time of storage or maintenance, the strains used in these experiments might have lost their plasmids; (3) Some plasmids may have conformations other than supercoiled DNA. ${ }^{8)}$ For the study of these possibilities, S. coelicolor A3(2) may be the best material and we are attempting to detect a plasmid in this strain.

\section{Acknowledgement}

We thank Mr. A. Serno (Kaken Kagaku Co.), Dr. N. ŌTAKE (Institute of Applied Microbiology, Tokyo University), Dr. M. Arai (Sankyo Co.), Dr. M. Mori (Kowa Co.), Dr. H. Kawaguchi (Bristol Banyu Co.) for their supply of actinomycete strains.

\section{References}

1) Okanishi, M.; T. Ohta \& H. Umezawa: Possible control of formation of aerial mycelium and antibiotic production in Streptomyces by episomic factors. J. Antibiotics 23: 45 47, 1970

2) Sankaran, L. \& B. M. Pogell: Biosynthesis of puromycin in Streptomyces alboniger: Regulation and properties of O-demethylpuromycin O-methyltransferase. Antimicr. Agents \& Chemoth. 8: 721 732, 1975

3) Shaw, P. D. \& J. Piwowarski: Effects of ethidium bromide and acriflavine on streptomycin production by Streptomyces bikiniensis. J. Antibiotics 30: 404 408, 1977

4) Akagawa, H.; M. Okanishi \& H. Umezawa: A plasmid involved in chloramphenicol production in Streptomyces venezuelae: evidence from genetic mapping. J. Gen. Microbiol. 90: 336 346, 1975

5) Akagawa, H.; M. Okanishi \& H. Umezawa: Genetics and biochemical studies of chloramphenicol nonproducing mutants of Streptomyces venezuelae carrying plasmid. J. Antibiotics 32: 610 620, 1979

6) Hopwood, D. A. \& M. J. Merrick: Genetics of antibiotics production. Bacteriol. Rev. 41: $595 \sim 635,1977$

7) Kirby, R. \& D. A. Hopwood: Genetic deter- mination of methylenomycin synthesis by the SCP1 plasmid of Streptomyces coelicolor A3(2). J. Gen. Microbiol. 98: 239 252, 1977

8) OKanishi, M. \& H. Umezawa: Plasmids involved in antibiotic production in Streptomycetes. Genetics of the Actinomycetales, ed. by E. Freerksen, I. Tarnok and J. H. Thumin. pp. 19 38, Gustav Fischer Verlag, Stuttgart New York, 1978

9) Malik, V. S.: Preparative method for the isolation of supercoiled DNA from a chloramphenicol producing Streptomycete. J. Antibiotics 31: 897 898, 1978

10) Yagisawa, M.; T-S. R. Huang \& J. E. Davies: Possible involvement of plasmids in biosynthesis of neomycin. J. Antibiotics 31: 809 813, 1978

11) Boronin, A. M. \& L. G. SAdovnikova: Elimination by acridine dyes of oxytetracycline resistance in Actinomyces rimosus. Genetika 8: $174 \sim 176,1972$

12) SchrempF, H. ; H. Bujard, D. A. Hopwood \& W. GoeBeL: Isolation of covalently closed circular deoxyribonucleic acid from Streptomyces coelicolor A3(2). J. Bacteriol. 121: 416 421, 1975

13) Bibb, M. J.; R. F. Freeman \& D. A. Hopwood: Physical and genetical characterization of a second sex factor, SCP2, for Streptomyces coelicolor A3(2). Molec. Gen. Genet. 154: 155 166, 1977

14) Okanishi, M. \& K. F. Gregory: Methods for the determination of deoxyribonucleic acid homologies in Streptomyces. J. Bacteriol. 140: 1086 1094, 1970

15) Davis, R. W.; M. Simon \& N. Davidson: Electron microscope heteroduplex methods for mapping regions of base sequence homology in nucleic acid. Methods in Enzymology. Vol. XXI, Nucleic acid Part D, ed. by L. Grossman and K. Moldave. pp. 413 428, Academic Press, New York and London, 1971

16) Haneishi, T.; N. Kitahara, Y. Takiguchi \& M. ARAI: New antibiotics, methylenomycin A and B. I. Producing organism, fermentation and isolation, biological activities and physical and chemical properties. J. Antibiotics 27:386 392, 1974

17) Haneishi, T.; A. Terahara, M. Arai, T. Hata \& C. TAmura: New antibiotics, methylenomycin A and B. II. Structures of methylenomycin A and B. J. Antibiotics 27: 393 399, 1974

18) Wright, L. F. \& D. A. Hopwood: Identification of the antibiotic determined by SCP1 plasmid of Streptomyces coelicolor A3(2). J. Gen. Microbiol. 95: 96 106, 1976 